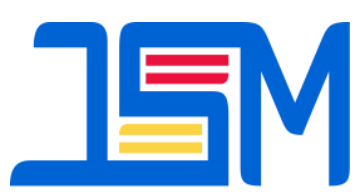

Jambura Science Of Management

\section{JAMBURA SCIENCE OF MANAGEMENT}

Homepage : http://ejurnal.ung.ac.id/index.php/jsm

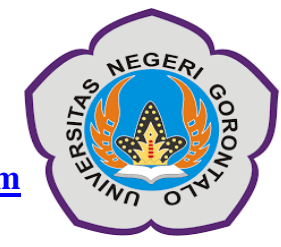

\title{
The Role of Discipline and Career Development in Improving Employee Work Achievement
}

\author{
Nailin Nikmatul Maulidiyah ${ }^{1}$, Moh. Samsul Arifin ${ }^{2}$, Dian Ary Setyawan ${ }^{3}$ \\ ${ }^{1,2}$ Sharia Finance Management, Faculty of Islamic Economics and Business, Universitas Islam \\ Zainul Hasan Genggong Probolinggo, Indonesia, East Java \\ ${ }^{3}$ Management, Faculty of Economics and Business, Universitas Jember, Indonesia, East Java \\ Email: nailinmaulidiyah@gmail.com
}

\begin{abstract}
:
This study aims to analyze the effect of discipline and career development on employee work achievement at PT. Bank Syariah Mandiri Jember Brach office. The population in this study is permanent employees at PT. Bank Syariah Mandiri Jember Brach office which numbered 54 employees. The analytical tool used in this study is multiple linear regression analysis to test the effect of the independent variable on the dependent variable. The results showed that the disciplinary significantly influence work achievement at PT. Bank Syariah Mandiri Jember Brach office. Career development significantly influenced work achievement at PT. Bank Syariah Mandiri Jember Branch Office. Simultaneously, discipline and career development significantly influenced work achievement at PT. Bank Syariah Mandiri Jember Branch Office.
\end{abstract}

\section{Keywords: Discipline; Career Development; Work Achievement}

Currently, every company is trying to show its advantages in order to stay afloat in increasingly fierce business competition. The company is demanded to increase the effectiveness and efficiency of its performance optimally so that the company's goals can be achieved. The process of achieving company goals is certainly not only determined by the sophistication of technology, facilities or infrastructure that is owned but also depends on the human resources they have. Human resources need to have reliable skills in handling every job, because with the existence of reliable skills it can directly improve work achievement. Mangkunegara (2015:67) argued that work achievement is the result of the quality and quantity of work achieved by an employee in carrying out their duties in accordance with the responsibilities given. Improving employee performance is very important in achieving the goals of an organization, one of which is by providing education and training for employees. Discipline is a factor that needs attention to improving employee work achievement. because humans have 
characteristics that are different from other resources. Humans have thoughts and feelings that determine actions including work discipline. According to Hasibuan (2016:193) discipline is the awareness and willingness of someone to obey company rules and social norms that apply. The better employee discipline, the higher work achievement can be achieved. Career development is intended so that employees have abilities that are higher than those previously possessed so that they can carry out their roles and responsibilities. Martoyo (2010:74) Said that Career development is a condition that indicates an increase in the status of a person in an organization in the career path that has been determined in the organization concerned. If employee career planning is in accordance with the career opportunities provided by the company, high morale will emerge. The suitability of career planning with career opportunities provided by the company can also be a motivation in working, so they will compete with each other to improve their work achievement. PT Bank Syariah Mandiri Jember Brach Office is a company engaged in financial services whose operations are based on sharia principles with the rules of agreement based on Islamic law between banks and other parties, especially those relating to depositing funds, financing business activities, and other activities in accordance with sharia. The employees of Bank Syariah Mandiri Jember Branch Office have different educational backgrounds, most of them are graduates of Islamic economics and study programs as well as study programs in other fields of science so that they need to be given education and short training for 10 working days on Islamic banking and then follow the program education and training in the company Employees have a fairly good discipline seen employees use their work hours as well as possible when after recess there is already at their respective workplaces. Through career opportunities available at the company. Employees adjust to career plans made by the company in order to achieve work achievement expected by the company and the employees themselves.

\section{METHOD}

The research design in this article is explanatory research namely research that explains the relationship between variables through hypothesis testing. The data used in this article is qualitative data which is quantitative. Data sources came from respondents, companies and the internet. Data obtained from respondents in the form of answers to questionnaires, data from the company in the form of the number of employees and organizational structure, and data from the internet in the form of company history of PT. Bank Syariah Mandiri Jember Branch Office. The population of this article is permanent employees at PT. Bank Syariah Mandiri Jember Branch Office with 54 employees. The sampling method used the census technique as a sample that is the entire population of 54 employees. To determine the effect of discipline and career development on employee performance, multiple linear regression analysis is used. 


\section{RESULT}

\section{The Classical Assumption Test 1. Model Normality Test}

The normality test in this article used the Kolmogorov Smirnov test for each variable. The data is normally distributed if the probability value $>0.05$ otherwise if the probability value $<0.05$ then the data is not normally distributed. Obtained a significance number of $0,766<0,05$, then it meets the model normality assumptions.

\section{Multicollinearity Test}

To determine the presence or absence of multicollinearity symptoms, the value of Variance Inflation Factor was used, value of VIF $<10$ means there are no symptoms of multicollinearity, vice versa if the value of
VIF > 10 regression model for variable $\mathrm{X} 1$, $\mathrm{X} 2$, and $\mathrm{X} 3$ have value of VIF under 10 So it can be concluded that there is no correlation between independent variables in this study or multicollinearity does not occur.

\section{Heteroscedasticity Test}

To find out whether in the regression model there is an inequality of variance from residuals in one observation to another. If the significance value $>0,05$ then heteroscedasticity does not occur. Based on the Glejser test results obtained a significance value of all variables greater than 0.05 so it was concluded that there was no heteroscedasticity.

Multiple Linear Regression Analysis

Table 1. Multiple Linear Regression Analysis Result

\begin{tabular}{ccccc}
\hline Variable & $\begin{array}{c}\text { Standardized } \\
\text { Coefficient }\end{array}$ & $\mathrm{t}$ - Count & $\mathrm{t}$-Table & Sig \\
\hline $\mathrm{X} 1$ & 0,371 & 2,160 & 2,036 & 0,038 \\
$\mathrm{X} 2$ & 0,352 & 2,092 & 2,036 & 0,044 \\
\hline
\end{tabular}

Source: Data processed

Based on the table, it can be seen the magnitude of the effect of each independent variable on the dependent variable as follows :

1. Effect Of Discipline (X1) On Work Achievement (Y)

The coefficient of discipline variable (X1) is 0.371 meaning that if discipline is better the work achievement will increase by a coefficient of 0.371 .
2. Effect Of Career Development (X1) On Work Achievement (X2)

The coefficient of career development (X2) is 0.352 means that if career development increases it can increase career development by a coefficient of 0.352 .

Hypothesis Testing

Partial Analysis (t- Test)

Table 2. Partial Analysis t-Test Result

\begin{tabular}{cccc}
\hline Variable & t- Count & t-Table & Sig \\
\hline X1 & 2,160 & 2,036 & 0,038 \\
X2 & 2,092 & 2,036 & 0,044 \\
\hline
\end{tabular}


Based on the table, it can be seen the magnitude of the effect of each independent variable on the dependent variable as follows :

1. Effect of discipline (X1) on work achievement (Y) Based on the table above it can be seen that $\mathrm{t}$ arithmetic from the discipline variable (X2) is 2.164 and the value of ttable 2.036 value from tcount $>$ ttable $(2.164>2.036)$. At the level of $\alpha=5 \%$, with a significance value $<\alpha(0.038<0.05)$, then $\mathrm{H} 0$ is rejected and $\mathrm{Ha}$ is accepted which means that there is a significant influence of discipline on work achievement.
2. Effect of career development (X2) on work achievement (Y) Based on the table above, it can be seen that $t$ arithmetic from career development variables (X3) is 2.092 and the value of 2.036 is value from tcount $>$ ttable (2.092> 2.036). At the level of $\alpha=5 \%$, with a significance value $<\alpha \quad(0.044$ $<0.05)$, then $\mathrm{HO}$ is rejected and $\mathrm{Ha}$ is accepted which means that there is a significant influence of career development on work achievement.

\section{Simultaneos Analysis (F-Test)}

Table 3. Simultaneos Analysis (F-Test) Result

\begin{tabular}{lcll}
\hline Variable & F Count & F Table & Sig \\
\hline & 21,202 & 2,900 & 0,000 \\
\hline
\end{tabular}

Source: Data processed

Based on the table above, obtained the calculated $F$ value of 21.202 with a significance value of 0,000 . F count $>F$ table $(21,202>2.90)$ and significance value $<0.05$ $(0,000<0.05)$ this means that the variables of discipline and career development have a joint (simultaneous) effect on work achievement.

\section{DISCUSSION}

\section{Effect of Discipline on Work Achievement}

Based on the partial test results ( $t$ test) obtained, the discipline has a significant effect on employee work achievement with a significance level of $\alpha=$ 5\%. Results and $\mathrm{HO}$ rejected mean that discipline has a positive and significant effect on work achievement. The results of this study are in line with research conducted by Supiatni (2011) which states that work discipline has a significant effect on work persuasion. The results of this study also support research Rofi (2012) which states that work discipline has a significant effect on work achievement. This is in accordance with the opinion Saydam (on sayudha, 2013), employees who did work without discipline will have a negative impact on the company which ultimately affects the employee's work achievement.

\section{Effect of Career Development on Work Achievement}

Based on the partial test results ( $t-$ test) obtained showed that career development has a significant effect on work achievement with a significance level of $\alpha=$ $5 \%$. These results indicated that the third 
hypothesis (H3) is accepted and $\mathrm{HO}$ is rejected, which means that career development has a positive and significant effect on work achievement. The results of this study are in line with the research conducted by Mariani (2016) which states that career development has a significant effect on work achievement. This is in accordance with Sudiro's opinion (in Dwi, 2014) Career planning and development aims to improve and enhance the effectiveness of the work carried out by employees in the hope that the employee will make the best contribution in realizing the company's goals. Contributions in this form in the form of work achievement generated by the employees.

\section{Effect Of Discipline And Career Development On Work Achievement}

Based on the results of simultaneous testing (f-test), a significant value of 0,000 was obtained with a significance level of $\alpha=$ $5 \%$, indicating that the fourth hypothesis (H4) was accepted stating that discipline and career development simultaneously had a significant effect on the work achievement of employees of PT Bank Syariah Mandiri Jember Branch Office. The results of this study prove that there is discipline, and good career development will have a positive impact on work achievement.

\section{CONCLUSION}

Discipline has a significant effect on the work achievement of employees of PT. Bank Syariah Mandiri Jember Branch Office. This proved that employees have high discipline in using their work hours to the maximum extent to produce high work achievement. Career development has a significant effect on the work achievement of employees of PT Bank Syariah Mandiri Jember Branch Office. This proves that employees have the same opportunity in developing their careers so employees will compete with each other to improve their work achievement in achieving that career. Discipline and career development simultaneously have a significant effect on the work achievement of employees of PT Bank Syariah Mandiri Jember Branch Office.

\section{REFERENCES}

Adhytia G. Tua. (2014). Konsep Diri, Pendidikan dan Pelatihan, Disiplin Kerja Terhadap Prestasi Kerja Pegawai di Kejaksaan Tinggi Sulawesi Utara. Jurnal EMBA Vol.2 No.1 Maret 2014, Hal. 353362.

Ahmad Nur Rofi, SE, M.Si. (2012). Pengaruh disiplin kerja dan pengalaman kerja Agung Raya Semarang. Jurnal Ilmu Manajemen dan Akuntansi Terapan, Vol 3 nomer 1 .

Dwi, Wahyuni. (2014). Pengaruh Pengembangan Karier Karyawan Terhadap Prestasi Kerja Karyawan (Studi pada Karyawan Tetap PT. Astra International, Tbk Daihatsu Malang). Jurnal Administrasi Bisnis $(J A B)$, Vol 8 No.1.

Handoko, T. Hani. (2014). Manajemen Personalia \& Sumber Daya Manusia. Edisi kedua. Cetakan XXI.Yogyakarta: BPFE

Hasibuan, Malayu. (2016). Manajemen Sumber Daya Manusia. Cetakan kesembilan. Jakarta : Bumi Aksara. 
Ita Mariani. (2016). Pengaruh Lingkungan Kerja dan Pengembangan Karir terhadap prestasi kerja karyawan PT Jaya Perkasa Sumatra. Jurnal ilmiah research sains Vol 2 No.1.

Mangkunegara, Anwar Prabu. (2015). Manajemen Sumber Daya Manusia . Bandung:Remaja Rosdakarya.

Martoyo, Susilo. (2010). Manajemen Sumber Daya Manusia. Yogyakarta: BPFE.

Ni Nyoman Supiatni. (2011). Pengaruh Kompensasi, Diklat dan Disiplin Kerja Terhadap Prestasi Kerja
Karyawan di Hotel Mercure Sanur. Jurnal Bisnis dan Kewirausahaan, Vol 7 no. 2.

Priyatno, Duwi. (2012). Cara Kilat Analisis Data dengan SPSS 20. Yogyakarta : Gava Media.

Sayudha Patria Adiputra. (2013)." Pengaruh Disiplin Kerja Terhadap Prestasi Kerja Karyawan Pada PT. Pimarindo Asia Infrastructure,Tbk Bandung". Dipublikasikan. Skripsi. Fakultas Bisnis Dan Manajemen universitas Widyatama 